\title{
Purification of a fibrinolytic protease from Mucor subtilissimus UCP 1262 by aqueous two-phase systems (PEG/sulfate)
}

\author{
Thiago Pajeú Nascimento ${ }^{\mathrm{a}}$, Amanda Emmanuelle Sales ${ }^{\mathrm{b}}$, Camila Souza Porto ${ }^{\mathrm{c}}$, \\ Romero Marcos Pedrosa Brandão ${ }^{\mathrm{b}}$, Galba Maria de Campos-Takaki ${ }^{\mathrm{d}}$, \\ José Antônio Couto Teixeira ${ }^{\mathrm{e}}$, Tatiana Souza Porto ${ }^{\mathrm{b}, \mathrm{f}}$, Ana Lúcia Figueiredo Porto ${ }^{\mathrm{b}}$, \\ Attilio Converti ${ }^{g}$,* \\ ${ }^{a}$ Laboratory of Immunopathology Keizo Asami (LIKA), Federal University of Pernambuco-UFPE, Av. Prof. Moraes Lins do Rego, 50670-901 Recife, \\ Pernambuco, Brazil \\ ${ }^{\mathrm{b}}$ Department of Morphology and Animal Physiology, Federal Rural University of Pernambuco-UFRPE, Rua Dom Manoel de Medeiros s/n, 52171-900 Recife, \\ Pernambuco, Brazil \\ c Unit of Penedo, Federal University of Alagoas-UFAL, Av. Duque de Caxias, 1074, 57200-000 Penedo, Alagoas, Brazil \\ d Center for Research in Environmental Sciences, Catholic University of Pernambuco-UNICAP, Rua do Príncipe, 526, 50050-900 Recife, Pernambuco, Brazil \\ e Center of Biological Engineering, University of Minho, Campus of Gualtar, 4710-057 Braga, Portugal \\ ${ }^{\mathrm{f}}$ Academic Unit of Garanhuns, Federal Rural University of Pernambuco-UFRPE, Avenida Bom Pastor, s/n, 55296-901 Garanhuns, Pernambuco, Brazil \\ ${ }^{g}$ Department of Civil, Chemical and Environmental Engineering, Pole of Chemical Engineering, University of Genoa-UNIGE, via Opera Pia 15, 16145 Genoa, \\ Italy
}

\section{A R T I C L E I N F O}

\section{Article history:}

Received 24 February 2016

Received in revised form 13 April 2016

Accepted 29 April 2016

Available online 3 May 2016

\section{Keywords:}

Mucor subtilissimus

Fibrinolytic protease

ATPS

\begin{abstract}
A B S T R A C T
A fibrinolytic protease from $M$. subtilissimus UCP 1262 was recovered and partially purified by polyethylene glycol (PEG)/sodium sulfate aqueous two-phase systems (ATPS). The simultaneous influence of PEG molar mass, PEG concentration and sulfate concentration on the enzyme recovery was first investigated using a $2^{3}$ full factorial design, and the Response Surface Methodology used to identify the optimum conditions for enzyme extraction by ATPS. Once the best PEG molar mass for the process had been selected $(6000 \mathrm{~g} / \mathrm{mol})$, a two-factor central composite rotary design was applied to better evaluate the effects of the other two independent variables. The fibrinolytic enzyme was shown to preferentially partition to the bottom phase with a partition coefficient $(K)$ ranging from 0.2 to 0.7 . The best results in terms of enzyme purification were obtained with the system formed by $30.0 \%$ (w/w) PEG $6000 \mathrm{~g} / \mathrm{mol}$ and $13.2 \%$ $(\mathrm{w} / \mathrm{w})$ sodium sulfate, which ensured a purification factor of $10.0, K$ of 0.2 and activity yield of $102.0 \%$. SDS-PAGE and fibrin zymography showed that the purified protease has a molecular mass of $97 \mathrm{kDa}$ and an apparent isoelectric point of 5.4. When submitted to assays with different substrates and inhibitors, it showed selectivity for succinyl-L-ala-ala-pro-L-phenylalanine-p-nitroanilide and was almost completely inhibited by phenylmethylsulfonyl fluoride, behaving as a chymotrypsin-like protease. At the optimum temperature of $37^{\circ} \mathrm{C}$, the enzyme residual activity was 94 and $68 \%$ of the initial one after 120 and $150 \mathrm{~min}$ of incubation, respectively. This study demonstrated that $M$. subtilissimus protease has potent fibrinolytic activity compared with similar enzymes produced by solid-state fermentation, therefore it may be used as an agent for the prevention and therapy of thrombosis. Furthermore, it appears to have the advantages of low cost production and simple purification.
\end{abstract}

(C) 2016 Elsevier B.V. All rights reserved.

\section{Introduction}

Mucor subtilissimus is a dimorphic fungus of the phylum of Zygomycota that can switch between yeast and filamentous growth structures depending on the environmental stimulus received [1].

\footnotetext{
* Corresponding author.

E-mail address: converti@unige.it (A. Converti).
}

This fungus belongs to the order of Mucorales also comprising the genera Rhizopus, Mucor, Rhizomucor, Cunninghamella and Absidia, which are known to have a potential for the production of milkclotting enzymes, lipases, amylases and extracellular proteases [2].

Proteases are a large and complex group of enzymes that play an important nutritional and regulatory role in nature [3]. These enzymes are considered the most important group of industrial enzymes with a great variety of industrial and biotechnological applications accounting for about $60 \%$ of the total enzyme 


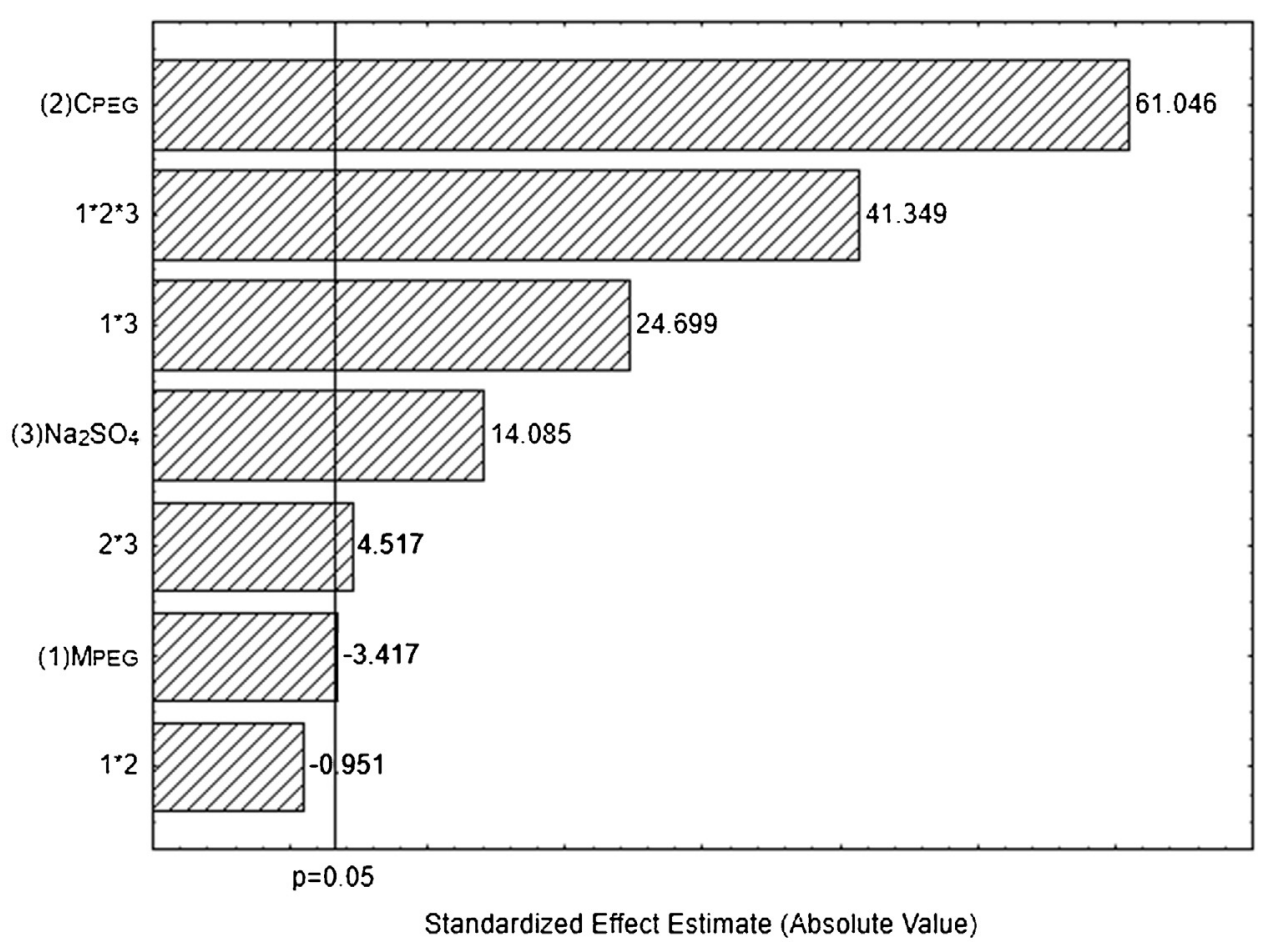

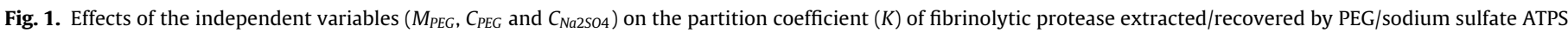
according to the preliminary $2^{3}$ full factorial design.

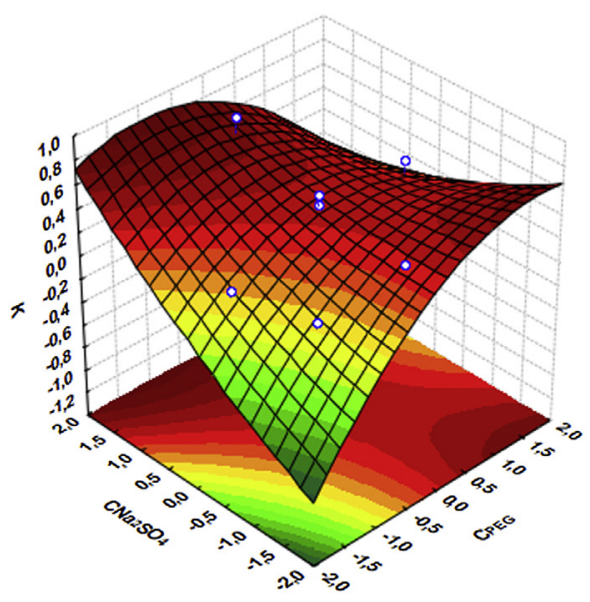

A

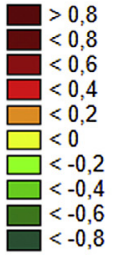

$-0,8$

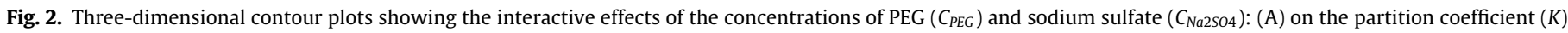
and (B) purification factor (PF) of fibrinolytic protease.

market worldwide and $40 \%$ of the total enzyme sales [3-5]. Fibrinolytic proteases are proteases that degrade fibrin, the major protein component of blood clots, whose accumulation leads to thrombosis that is responsible for cardiovascular diseases including myocardial infarction [6].

In recent years, several studies have been made to search for new sources of thrombolytic agents such as bacteria, algae, plants, worms, snake venom, insects, and fungi [6-10]. Filamentous fungi have been shown to be a good choice for the production of fibrinolytic enzymes, since they produce them in large amounts mostly extracellularly, which makes their extraction/purification easier [11].

Partitioning in aqueous two-phase systems (ATPS) is an effective method for separating and purifying mixtures of biomolecules

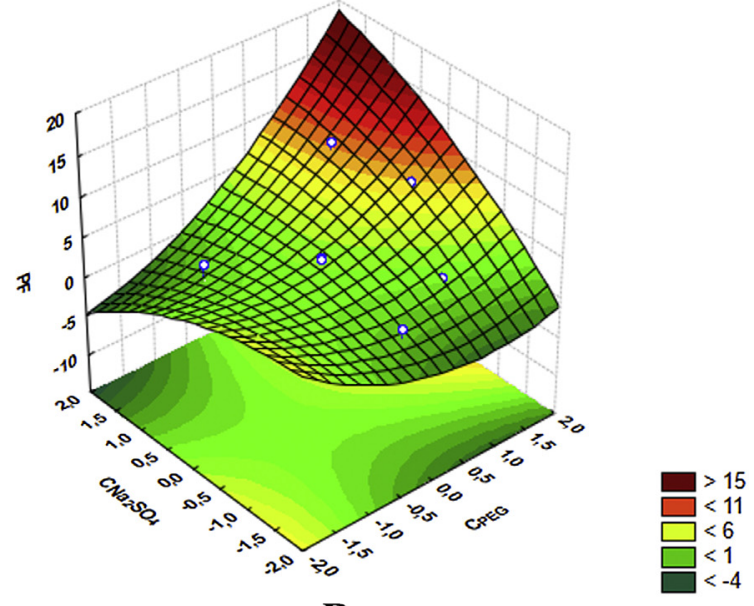

B
[12-15], which is suitable for large-scale production in an environmentally friendly way. Traditional techniques such as chromatography and ammonium sulfate precipitation are slowly being replaced, especially in the primary steps of proteases purification, by extraction/purification methods like ATPS, because of their lower costs of production and operation $[6,12,16,17]$.

Aiming to optimize the conditions of purification of these enzymes, to reduce their costs, the amount of work and time, some theoretical tools have been used. Among these, the Response Surface Methodology (RSM) is a collection of mathematical and statistical techniques that are useful for modeling and analysis in applications where a response of interest (or output) is influenced by several factors. The objective of RSM is to optimize such a response [18-20] through experimental design, model fitting, 
validation and optimization steps, using a minimum number of experiments for a large number of factors. It was already applied successfully to improve the production and/or purification of several enzymes [21,22].

Based on such a background, the objective of this study was to select the optimal operation conditions for the purification of fibrinolytic protease from Mucor subtilissimus UCP 1262 by ATPS using RSM.

\section{Material and methods}

\subsection{Microorganism}

The filamentous fungi Mucor subtilissimus UCP 1262 used in this study was isolated from the soil of Caatinga, PE-Brazil, deposited and gentle provided by the Catholic University of Pernambuco (UCP) Culture Collection. It was maintained on Czapek medium at $30^{\circ} \mathrm{C}$ for 7 days and stored in mineral oil.

\subsection{Preparation of inoculum}

Spores were collected using a nutrient solution comprised of $0.5 \%$ yeast extract, $1 \%$ glucose, $0.01 \%$ Tween 80 , diluted in previously sterilized $245 \mathrm{mM}$ sodium phosphate buffer, $\mathrm{pH}$ 7.0. They were counted in a Neubauer chamber to give a final concentration of $10^{7}$ spores $/ \mathrm{mL}$.

\subsection{Production of fibrinolytic protease by solid-state fermentation}

$125 \mathrm{~mL}$-Erlenmeyer flasks containing $3.0 \mathrm{~g}$ of wheat bran as a substrate (moisture content of $50 \%$ ) were sterilized by autoclaving at $121^{\circ} \mathrm{C}, 1 \mathrm{~atm}$ for $20 \mathrm{~min}$, inoculated with the above suspension of $M$. subtilissimus UCP 1262 spores, and incubated at $25^{\circ} \mathrm{C}$ for $72 \mathrm{~h}$. Both the microorganism and the substrate were chosen based on previous work [23].

\subsection{Enzyme extraction}

Enzyme extraction was performed after $72 \mathrm{~h}$ of fermentation. For this purpose, $7.5 \mathrm{~mL}$ of $245 \mathrm{mM}$ sodium phosphate buffer, $\mathrm{pH}$ 7 , were added per $\mathrm{g}$ of substrate, and the flasks were placed in an orbital shaker at $150 \mathrm{rpm}$ for $90 \mathrm{~min}$ at room temperature, as previously described [23]. Samples were then centrifuged at $3500 \mathrm{rpm}$ for $10 \mathrm{~min}$, and the supernatant was used for determination of protease and fibrinolytic activities.

\subsection{Protease activity}

Protease activity was measured as described by Ginther [24]. Assay mixtures of $1.0 \mathrm{~mL}$, containing $0.2 \mathrm{M}$ TRIS hydrochloride, $\mathrm{pH}$ $7.2,10^{-3} \mathrm{M} \mathrm{CaCl}_{2}, 1 \%$ azocasein and $150 \mu \mathrm{L}$ of spent medium, were incubated at $28^{\circ} \mathrm{C}$ for $1 \mathrm{~h}$. After stopping the reaction by the addition of $1.0 \mathrm{~mL}$ of $10 \%$ trichloroacetic acid, samples were centrifuged at $3000 \mathrm{~g}$ for $15 \mathrm{~min}$, and $0.8 \mathrm{~mL}$ of the supernatant was transferred into a second tube containing $0.2 \mathrm{~mL}$ of $1.8 \mathrm{~N} \mathrm{NaOH}$. Samples were finally blended in a Vortex mixer, and the absorbance was measured at $420 \mathrm{~nm}$. One unit of protease activity was defined as the amount of enzyme responsible for a 0.1 increase per hour in the absorbance.

\subsection{Fibrinolytic activity}

The fibrinolytic activity $(F A)$ was determined using the spectrophotometric method described by Wang et al. [25]. Briefly, $0.4 \mathrm{~mL}$ of $0.15 \mathrm{M}$ TRIS $\mathrm{HCl}-\mathrm{NaCl}$, pH 7.75, with $0.72 \%$ fibrinogen was placed in a test tube containing $0.1 \mathrm{~mL}$ of $245 \mathrm{mM}$ phosphate buffer, $\mathrm{pH} 7$, and incubated at $37^{\circ} \mathrm{C}$ for $5 \mathrm{~min}$. After addition of $0.1 \mathrm{~mL}$ of $20 \mathrm{U} / \mathrm{mL}$ thrombin solution and further incubation for $10 \mathrm{~min}$, $0.1 \mathrm{~mL}$ of diluted enzyme solution was added. After addition of $0.7 \mathrm{~mL}$ of $0.2 \mathrm{M}$ trichloroacetic acid, the resulting solution was incubated at $37^{\circ} \mathrm{C}$ for $1 \mathrm{~h}$ and homogenized for 20,40 and $60 \mathrm{~min}$. The reaction mixture was then centrifuged at $15,000 \times \mathrm{g}$ for $10 \mathrm{~min}$, and $1.0 \mathrm{~mL}$ of the supernatant collected to read the absorbance at $275 \mathrm{~nm}$. One fibrin degradation unit (U) of enzyme activity was defined as the amount of enzyme able to cause a 0.01 increase per minute in the absorbance. Each experiment was performed in triplicate, and the results, after correction against blank samples, were expressed as mean values.

\subsection{Protein determination}

Total protein content of samples was determined according to Bradford [26] using Coomassie Brilliant Blue G-250 as a dye and Bovine Serum Albumin as a standard. Each experiment was performed in triplicate, and the results, after correction against blank samples, were expressed as mean values.

\subsection{Preparation of the aqueous two-phase systems}

Aqueous two-phase systems (ATPS) were prepared at $25 \pm 1{ }^{\circ} \mathrm{C}$ in $15 \mathrm{~mL}$-graduated tubes with equal masses of sodium sulfate and PEG solutions with different concentrations. Water was added to $2.0 \mathrm{~g}$ of crude extract up to a final weight of $10 \mathrm{~g}$ at $37^{\circ} \mathrm{C}$. After addition of all ATPS components and vortex shaking for $1.0 \mathrm{~min}$, the top and bottom phases were separated by settling for $60 \mathrm{~min}$, and their respective volumes ( $V_{t}$ and $V_{b}$, respectively) measured. Both phases were finally assayed for protein and fibrinolytic activity determinations.

\subsection{Determination of ATPS parameters}

The partition coefficient of fibrinolytic protease was defined as the ratio of fibrinolytic activity, expressed in $\mathrm{U} / \mathrm{mL}$, in the top phase $\left(F A_{t}\right)$ to that in the bottom phase $\left(F A_{b}\right)$ :

$K=\frac{F A_{t}}{F A_{b}}$

The activity yield was determined as the ratio of total activity in the top or bottom phase to that in the crude extract $\left(F A_{i}\right)$ and expressed as percentage. For this purpose, $F A_{t}$ or $F A_{b}$ was multiplied by $V_{t}$ or $V_{b}$, respectively, and $F A_{i}$ by the total volume of the crude extract $\left(V_{i}\right)$ :

$Y_{t, b}=\left(\frac{F A_{t, b} \cdot V_{t, b}}{F A_{i} \cdot V_{i}}\right) \times 100$

The specific activity $(S A)$ was defined as the ratio of the enzyme activity $(\mathrm{U} / \mathrm{mL})$ to the protein concentration $(\mathrm{mg} / \mathrm{mL})$.

The purification factor in the top or bottom phase was calculated as the ratio of the respective specific activity $\left(S A_{t}\right.$ or $\left.S A_{b}\right)$ to the specific activity of the crude extract $\left(S A_{i}\right)$, all expressed in $\mathrm{U} / \mathrm{mg}$ :

$P F_{t, b}=\frac{S A_{t, b}}{S A_{i}}$

\subsection{Factorial design for preliminary selection of purification parameters}

The influence of the independent variables, namely PEG molar mass $\left(M_{P E G}\right)$, PEG concentration $\left(C_{P E G}\right)$, and sodium sulfate concentration $\left(C_{\mathrm{Na} 2 \mathrm{SO} 4}\right)$ on the responses, namely $K, F A_{b}, Y_{b}$ and $P F_{b}$, was first investigated according to a $2^{3}$ factorial design with four 


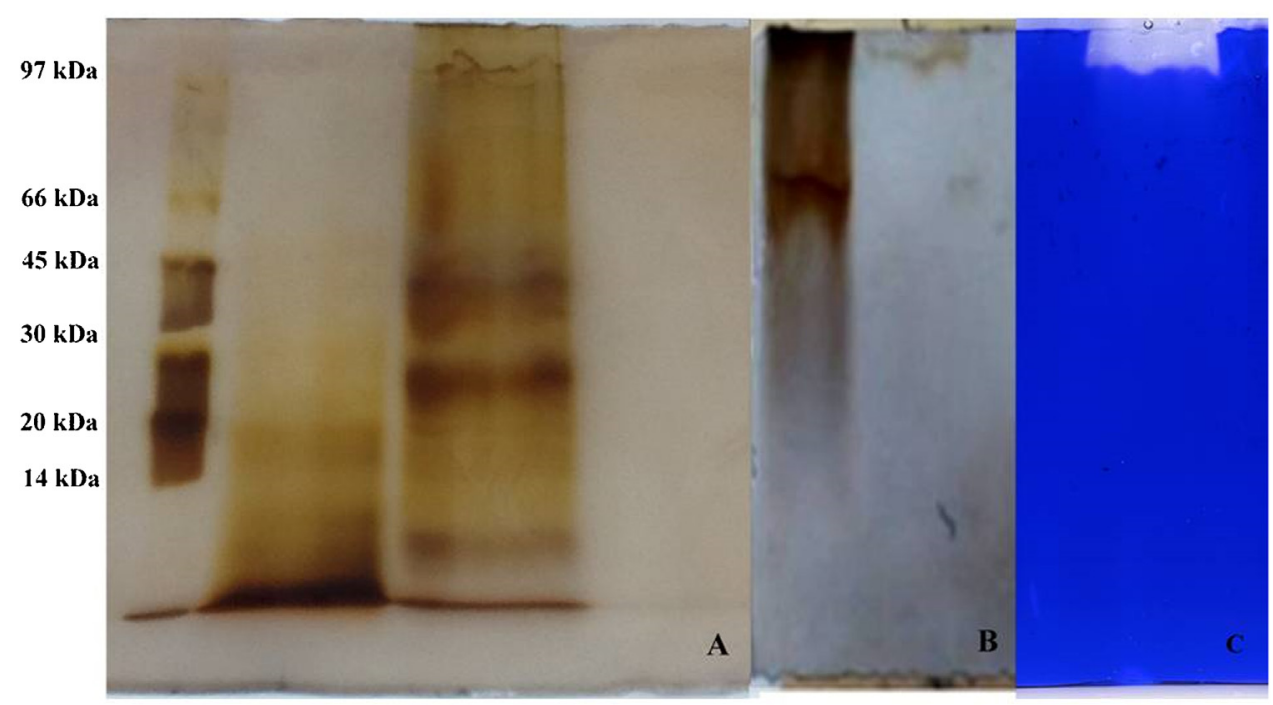

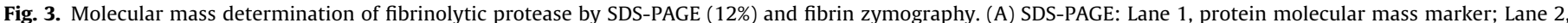

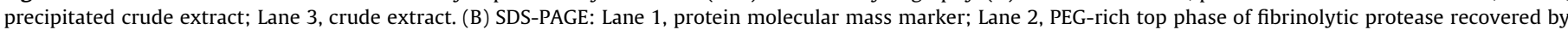

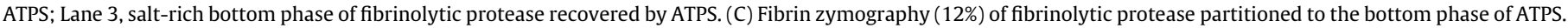

replicates at the central point to allow for the estimation of pure experimental error [27].

\subsection{Determination of the optimal conditions for proteases purification by two-factor central composite rotary design}

To find the optimum conditions for purification of fibrinolytic protease by ATPS, we used a two-factor central composite rotary design (CCRD), where $C_{P E G}$ and $C_{N a 2 S O 4}$ were selected as the independent variables, and the fibrinolytic activity, activity yield and purification factor in the bottom phase and the partition coefficient as the responses. Such a design was centered on those values of variables that had ensured the highest purification factor according to the previous factorial design. The coded values for the independent variables were -1.4142 (lowest level), $-1,0,+1$, and +1.4142 (highest level). The complete design consisted of 12 experiments with four replicates at the central point carried out in random order. The Response Surface Methodology (RSM) was used to better visualize and compare results [18-21].

\subsection{Sodium dodecyl sulfate-polyacrylamide gel electrophoresis}

Sodium dodecyl sulfate-polyacrylamide gel electrophoresis (SDS-PAGE) was carried out using a $12 \%$ polyacrylamide running gel according to the method of Laemmli [28]. The molecular mass was calibrated using as a standard a molecular mass marker (GE Healthcare 17044601, São Paulo, SP, Brazil) containing (a) phosphorylase b: $67 \mu \mathrm{g}$, relative molecular mass (Mr) of 97,000, rabbit muscle (source), (b) albumin: $83 \mu \mathrm{g}, 66,000(\mathrm{Mr})$, bovine serum (source), (c) ovalbumin: $147 \mu \mathrm{g}, 45,000(\mathrm{Mr})$, chicken egg white (source), and (d) carbonic anhydrase: $83 \mu \mathrm{g}, 30,000$ (Mr), bovine erythrocyte (source). Protein bands were detected by staining with Coomassie Brilliant Blue G-250.

\subsection{3. $2 D$ two-dimensional electrophoresis}

The fibrinolytic enzyme purified by ATPS was dialyzed in $24 \mathrm{mM}$ buffer sodium phosphate, $\mathrm{pH}$ 7.0, lyophilized and resolubilized in buffer-2 [7 M urea; $2 \mathrm{M}$ thiourea; $85 \mathrm{mM}$ DL-dithiothreitol (DTT); 2.5\% (v/v) Triton X-100 $\left(\mathrm{C}_{34} \mathrm{H}_{62} \mathrm{O}_{11}\right) ; 0.5 \%(\mathrm{v} / \mathrm{v})$ Pharmalyte $^{\mathrm{TM}}$; $10 \%(\mathrm{v} / \mathrm{v})$ isopropanol]. The resulting solution was used to rehydrate $18 \mathrm{~cm}$-long strips (IPG ReadyStrip, Bio-Rad, Rio de Janeiro,
Brazil) containing fixed, linear $\mathrm{pH}$ gradient (IPG), $\mathrm{pH} 3-10 / \mathrm{pH}$ $4-7$, for $17 \mathrm{~h}$. The rehydrated strips were subjected to isoelectric focusing in IPGPhor system (GE Healthcare, São Paulo, SP, Brazil) in manifold system. The focus was performed in four successive steps that depended on the $\mathrm{pH}$ range at which the focus was carried out, namely $\mathrm{pH} 3-10$ : step-and-hold $500 \mathrm{~V} / 1 \mathrm{H}$, gradient of $500 \mathrm{~V}-1000 \mathrm{~V} / 1 \mathrm{~h}$, gradient- $1000 \mathrm{~V} 8000 \mathrm{~V} / 3 \mathrm{~h} 45$, and step-andhold $8000 \mathrm{~V} / 45 \mathrm{~min}$. Strips were then put into a solution containing DTT to disrupt disulfide bridges ( $\mathrm{S}-\mathrm{S}$ bonds) present in the protein, SDS to facilitate the access to the internal parts of the protein due to disruption of its tertiary structure, and iodoacetamide to avoid reoxidation of thiol groups (alkylation).

\subsection{Fibrin zymography}

Fibrinolytic activity was analyzed by means of a fibrin zymography gel as described by Kim et al. [29]. Fibrinogen and thrombin were mixed with $12 \%$ polyacrylamide gel solution, and electrophoresis of protease solution was carried out. A molecular mass marker was uses as a standard. After electrophoresis, the gel was washed with $2.5 \%$ Triton $\mathrm{X}-100$ for $1 \mathrm{~h}$, rinsed thrice with distilled water, and incubated in the reaction buffer ( $0.1 \mathrm{M}$ glycine, $\mathrm{pH} 8.4)$ at $37^{\circ} \mathrm{C}$ for $18 \mathrm{~h}$. The gel was stained with Coomassie blue for $1 \mathrm{~h}$ and then destained. The digested bands were visualized as the nonstained regions of the fibrin gel.

\subsection{Amidolytic activity}

Amidolytic activity was measured as described by Kim et al. [30] using synthetic substrates, namely succinyl-L-alaala-pro-L-phenylalanine-p-nitroanilide (SAPNA, S7388 Sigma), gly-arg-p-nitroanilide dihydrochloride (G8148 Sigma) and $N \alpha$ benzoyl-DL-arginine 4-nitroanilide hydrochloride (B4875 Sigma).

\subsection{Effect of metal ions on protease activity}

Protease activity of the enzyme purified from the salt-rich bottom phase was evaluated in the presence of metal ions described as inhibitors or activators of protease activity, whose effect was evaluated at concentrations of $2.5,5.0$ and $10 \mathrm{mM}$. The crude extract was exposed to the following ions: zinc $\left(\mathrm{Zn}^{++}\right)$, magnesium $\left(\mathrm{Mg}^{++}\right)$, copper $\left(\mathrm{Cu}^{++}\right)$, ferrous $\left(\mathrm{Fe}^{++}\right)$, calcium $\left(\mathrm{Ca}^{++}\right)$, manganese $\left(\mathrm{Mg}^{++}\right)$, 
sodium $\left(\mathrm{Na}^{+}\right)$, potassium $\left(\mathrm{K}^{+}\right)$and cobalt $\left(\mathrm{Co}^{++}\right)$, and incubated at $37^{\circ} \mathrm{C}$ for $60 \mathrm{~min}$. The ions were dissolved in TRIS- $\mathrm{HCl}, \mathrm{pH} 7.75$, containing $150 \mathrm{mM} \mathrm{NaCl}$.

\subsection{Effect of inhibitors on protease activity}

To evaluate the effect of inhibitors on protease activity, the enzyme purified from the salt-rich bottom phase was exposed to the following inhibitors: phenylmethylsulfonyl fluoride (PMSF), 2-mercaptoethanol, ethylenediaminetetraacetic acid (EDTA-acetic- $\mathrm{C}_{10} \mathrm{H}_{16} \mathrm{~N}_{2} \mathrm{O}_{8}$ ), pepstatin A and iodoacetic acid. Each inhibitor was dissolved according to the protocol provided by Sigma and incubated for $60 \mathrm{~min}$ at $37^{\circ} \mathrm{C}$ with the enzyme solution at a fixed concentration $(5.0 \mathrm{mM})$.

\subsection{Effect of temperature on protease activity and stability}

The effect of temperature was investigated by incubating the enzyme purified from the salt-rich bottom phase at the temperatures $10,20,30,40,50,60,70,80$ and $90^{\circ} \mathrm{C}$. To determine the stability to temperature, aliquots were withdrawn at the beginning and after 15, 30, 60, 90, 120, 150 and $180 \mathrm{~min}$ and then submitted to determination of protease activity.

\subsection{Statistical analysis}

Statistical analysis of results obtained through the factorial experimental design and central composite rotary design were performed using the software Statistical 8.0. In order to compare the means of the effects of inhibitors on protease activity, we used the Student $t$-test for independent samples. The results were considered statistically significant at $p \leq 0.05$.

\section{Results and discussion}

\subsection{Preliminary selection of ATPS for fibrinolytic protease extraction}

The experimental results of the partition coefficient $(K)$ of the fibrinolytic protease listed in Table 1 show that in most of the $\mathrm{PEG} / \mathrm{Na}_{2} \mathrm{SO}_{4}$ ATPS runs the enzyme partitioned preferentially to the bottom salt-rich phase $(K<1)$, consistently with the observations of Sales et al. [31] for fibrinolytic proteases from Bacillus sp. UFPEDA 485. On the other hand, values of $K>1$ in runs 3, 4, 7 and 8 point out that, at the highest PEG concentration $\left(C_{P E G}=30.0 \%\right.$ $\mathrm{w} / \mathrm{w})$, the enzyme preferentially partitioned to the top PEG-rich phase likely due its high hydrophobicity $[12,31,32]$ or to a salting out effect $[6,31,32]$. As shown in Fig. 1, $C_{P E G}$ influenced positively the enzyme partition although also sodium sulfate concentration $\left(C_{\mathrm{Na2SO4}}\right)$ and PEG molar mass $\left(M_{P E G}\right)$ exerted weaker positive and negative effects, respectively. Similarly, Medeiros e Silva et al. [6] observed a positive effect of $C_{P E G}$ and a negative one of $M_{P E G}$ on the partition of fibrinolytic proteases in PEG/phosphate ATPS.

The highest values of the activity yield in the bottom phase $\left(Y_{b}\right)(106.0-130.0 \%)$ were obtained in the central point runs carried out at $M_{P E G} 6000 \mathrm{~g} / \mathrm{mol}, C_{P E G} 24.0 \%(\mathrm{w} / \mathrm{w})$ and $C_{N a 2 S O 4} 11.6 \%(\mathrm{w} / \mathrm{w})$ (Table 1). Yield values higher than $100 \%$ as in the present case may be associated with removal of contaminants and inhibitors during the partition, which increases the enzyme activity [33,34]. Central point runs also ensured the highest values of the purification factor in the bottom phase ( $P F_{b}$ of 3.2 and 4.5$)$, which are in agreement with those (up to 4.0 ) reported for a fibrinolytic protease extracted by PEG/potassium phosphate ATPS [35].

\subsection{Optimization of fibrinolytic protease partition by two-factor central composite rotary design}

As previously mentioned, the conditions of fibrinolytic protease partition were optimized through a set of 12 additional runs carried out according to a two-factor central composite rotary design (CCRD), where $C_{P E G}$ and $C_{N a 2 S O 4}$ were selected as the independent variables and $F A_{b}, K, Y_{b}$ and $P F_{b}$ as the responses. One can see in Table 2, which summarizes the conditions and results of these runs, that all these responses varied in very wide ranges $\left(34.6 \leq F A_{b} \leq 94.2 \mathrm{U} / \mathrm{mL}, 0.0 \leq K \leq 0.7,47.5 \leq Y_{b} \leq 177.0 \%\right.$ and $\left.1.6 \leq P F_{b} \leq 10.0\right)$, suggesting strong influence of the selected variables on them. The run 4 , carried out using $C_{P E G}=30.0 \%(\mathrm{w} / \mathrm{w})$ and $C_{\mathrm{Na} 2 \mathrm{SO} 4}=13.2 \%(\mathrm{w} / \mathrm{w})$, allowed for the best results in terms of purification factor $\left(P F_{b}=10.0\right)$ as well as a quite high activity yield $\left(Y_{b}=102.0 \%\right)$ in the bottom phase (Table 2$)$. This $P F_{b}$ value is higher than those obtained at the beginning of this work using the preliminary factorial design $\left(P F_{b}=3.2\right.$ up to 4.5$)$ as well as those reported for the extraction of fibrinolytic protease from Streptomyces sp. DPUA1576 by PEG/phosphate ATPS (1.51) [6].

Table 3 lists the linear (L) and quadratic (Q) effects of the independent variables as well as their interactions on the selected responses. One can see that the only statistically significant effects on $Y_{b}$ and $F A_{b}$ were the linear one of $C_{P E G}$ and the quadratic one of $C_{\mathrm{Na2SO}}$, respectively, being both negative. From Fig. 2, which illustrates, as an example, the three-dimensional graph obtained applying the Response Surface Methodology to the experimental results of $K$ and $P F_{b}$, it is evident the significant combined effect of $C_{P E G}$ and $C_{N a 2 S O 4}$ on these responses. As reported by Ashipala and $\mathrm{He}$ [21], the fibrinolytic activity of an enzyme produced from Bacillus subtilis DC-2, after extraction by PEG $4000 / \mathrm{Na}_{2} \mathrm{SO}_{4}$ ATPS performed according to a similar CCRD, was mainly dependent on $C_{P E G}$ and $C_{\mathrm{Na2SO} 4}$ besides $\mathrm{pH}$.

Since $P F_{b}$, which is by far the most important response for the purposes of this work, has given the best results compared to literature, it was submitted to the analysis of variance. The F-value for the overall regression model was significant at $5 \%$ level, the coefficient of determination satisfactory $\left(R^{2}=0.8584\right)$ and the lack of fit insignificant (Table 4), hence indicating that the first-order model with interaction was adequate to represent the response surface of this response for fibrinolytic protease obtained according to the selected CCRD.

\section{3. $2 D$ two-dimensional SDS-PAGE and fibrin zymography}

SDS-PAGE and fibrin zymography were performed to check the purity degree of fibrinolytic protease from Mucor subtilissimus UCP 1262 that preferentially partitioned to the bottom phase after extraction by ATPS under the best conditions selected according to the CCRD, namely $C_{P E G}$ of $30.0 \%(\mathrm{w} / \mathrm{w})$ and $C_{\mathrm{Na} 2 \mathrm{SO} 4}$ of $13.2 \%$ $(\mathrm{w} / \mathrm{w})$. One can see in Fig. $3 \mathrm{~B}$ that the enzyme had a molecular mass ( $97 \mathrm{kDa})$ consistent with those reported for novel fibrinolytic enzymes of Schizophyllum commune BL23 (66-97 kDa) [36] and Bionectria sp. isolated from Las Yungas rainforest $(80-173 \mathrm{kDa})$ [37], but significantly higher than those reported for fibrinolytic enzymes from Fusarium sp. BLB (20-30 kDa) [38], Rhizopus chinensis 12 (17-18 kDa) [39], Pleurotus eryngii (14 kDa) [40] and Schizophyllum commune [41] (21 $\mathrm{kDa})$. The above molecular mass value is practically coincident with that revealed by fibrin zymography of the enzyme partitioned to the bottom phase (Fig. 3C). In addition, SDS-PAGE (12\%) revealed an apparent isoelectric point of 5.4 (result not shown), which is characteristic of an acidic protease. 
Table 1

Results of fibrinolytic protease extraction/recovery by PEG/sodium sulfate ATPS according to the preliminary $2^{3}$ full factorial design.

\begin{tabular}{|c|c|c|c|c|c|c|c|c|c|c|}
\hline Run & $\begin{array}{l}M_{P E G}{ }^{\mathrm{a}} \\
(\mathrm{g} / \mathrm{mol})\end{array}$ & $\begin{array}{l}C_{P E G}{ }^{\mathrm{b}} \\
(\% \mathrm{w} / \mathrm{w})\end{array}$ & $\begin{array}{l}C_{\mathrm{Na} 2 \mathrm{SO} 4}^{\mathrm{c}} \\
(\% \mathrm{w} / \mathrm{w})\end{array}$ & $\begin{array}{l}F A_{t}{ }^{\mathrm{d}} \\
(\mathrm{U} / \mathrm{mL})\end{array}$ & $\begin{array}{l}F A_{b}{ }^{\mathrm{e}} \\
(\mathrm{U} / \mathrm{mL})\end{array}$ & $K^{\mathrm{f}}$ & $\begin{array}{l}Y_{t}^{g} \\
(\%)\end{array}$ & $\begin{array}{l}Y_{b}{ }^{\mathrm{h}} \\
(\%)\end{array}$ & $P F_{t}{ }^{i}$ & $P F_{b}{ }^{j}$ \\
\hline 1 & 4000 & 18.0 & 10.0 & 11.7 & 44.2 & 0.2 & 19.0 & 73.3 & 1.0 & 0.8 \\
\hline 2 & 8000 & 18.0 & 10.0 & 24.2 & 47.1 & 0.5 & 35.1 & 81.4 & 1.5 & 0.9 \\
\hline 3 & 4000 & 30.0 & 10.0 & 19.2 & 9.5 & 2.0 & 40.4 & 9.61 & 1.0 & 0.8 \\
\hline 4 & 8000 & 30.0 & 10.0 & 15.8 & 12.1 & 1.3 & 32.85 & 12.53 & 0.7 & 1.0 \\
\hline 5 & 4000 & 18.0 & 13.2 & 20.8 & 28.7 & 0.7 & 28.8 & 49.7 & 1.7 & 0.6 \\
\hline 6 & 8000 & 18.0 & 13.2 & 14.6 & 37.5 & 0.3 & 20.2 & 64.8 & 0.7 & 1.1 \\
\hline 7 & 4000 & 30.0 & 13.2 & 17.5 & 15.0 & 2.3 & 169.0 & 35.0 & 3.5 & 2.0 \\
\hline 8 & 8000 & 30.0 & 13.2 & 11.2 & 5.00 & 2.2 & 22.6 & 5.1 & 0.6 & 0.6 \\
\hline $9^{\mathrm{k}}$ & 6000 & 24.0 & 11.6 & 23.7 & 57.1 & 0.8 & 128.0 & 130.0 & 2.5 & 3.2 \\
\hline $10^{\mathrm{k}}$ & 6000 & 24.0 & 11.6 & 20.8 & 52.9 & 0.8 & 121.0 & 124.0 & 2.6 & 3.6 \\
\hline $11^{\mathrm{k}}$ & 6000 & 24.0 & 11.6 & 20.4 & 57.1 & 0.5 & 70.2 & 106.0 & 1.5 & 3.2 \\
\hline $12^{\mathrm{k}}$ & 6000 & 24.0 & 11.6 & 22.1 & 55.0 & 0.5 & 78.9 & 116.0 & 2.0 & 4.5 \\
\hline
\end{tabular}

a $M_{P E G}=$ PEG molar mass.

b $C_{P E G}=$ PEG concentration.

c $C_{\text {Na2SO4 }}=$ Sodium sulfate concentration.

d $F A_{t}=$ Fibrinolytic activity in the top phase.

e $F A_{b}=$ Fibrinolytic activity in the bottom phase.

f $K=$ Partition coefficient.

g $Y_{t}=$ Activity yield in the top phase.

h $Y_{b}=$ Activity yield in the bottom phase.

i $P F_{t}=$ Purification factor in the top phase.

${ }^{\mathrm{j}} P F_{b}=$ Purification factor in the bottom phase.

$\mathrm{k}$ Central point runs.

Table 2

Results of the two-factor central composite rotary design used to optimize the extraction/recovery of fibrinolytic protease by PEG 6000/sodium sulfate ATPS.

\begin{tabular}{|c|c|c|c|c|c|c|}
\hline Run & $\begin{array}{l}C_{P E G^{\mathrm{a}}} \\
(\% \mathrm{w} / \mathrm{w})\end{array}$ & $\begin{array}{l}C_{\mathrm{Na} 2 \mathrm{SO} 4}{ }^{\mathrm{b}} \\
(\% \mathrm{w} / \mathrm{w})\end{array}$ & $\begin{array}{l}F A_{b}{ }^{c} \\
(\mathrm{U} / \mathrm{mL})\end{array}$ & $K^{\mathrm{d}}$ & $\begin{array}{l}Y_{b}{ }^{\mathrm{e}} \\
(\%)\end{array}$ & $P F_{b}{ }^{\mathrm{f}}$ \\
\hline 1 & 18.0 & 10.0 & 94.2 & 0.0 & 177.0 & 2.0 \\
\hline 2 & 18.0 & 13.2 & 71.7 & 0.4 & 138.0 & 2.2 \\
\hline 3 & 30.0 & 10.0 & 93.3 & 0.4 & 78.0 & 1.9 \\
\hline 4 & 30.0 & 13.2 & 76.2 & 0.2 & 102.0 & 10.0 \\
\hline 5 & 15.6 & 11.6 & 84.2 & 0.1 & 176.0 & 2.1 \\
\hline 6 & 32.4 & 11.6 & 51.2 & 0.4 & 47.5 & 7.7 \\
\hline 7 & 24.0 & 9.36 & 57.5 & 0.3 & 74.5 & 1.3 \\
\hline 8 & 24.0 & 13.8 & 34.6 & 0.7 & 56.4 & 1.6 \\
\hline $9^{g}$ & 24.0 & 11.6 & 90.0 & 0.4 & 143.0 & 3.8 \\
\hline $10^{g}$ & 24.0 & 11.6 & 89.6 & 0.4 & 127.0 & 3.6 \\
\hline $11^{g}$ & 24.0 & 11.6 & 87.9 & 0.5 & 99.3 & 2.0 \\
\hline $12^{g}$ & 24.0 & 11.6 & 88.3 & 0.3 & 118.0 & 3.4 \\
\hline
\end{tabular}

a $C_{P E G}=$ PEG 6000 concentration.

b $\mathrm{C}_{\mathrm{Na2SO4}}=$ Sodium sulfate concentration.

c $F A_{b}=$ Fibrinolytic activity in the bottom phase.

d $K=$ Partition coefficient.

e $Y_{b}=$ Activity yield in the bottom phase.

f $P_{b}=$ Purification factor in the bottom phase.

g Central point runs.

Table 3

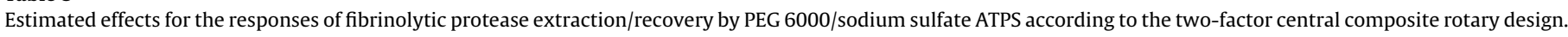

\begin{tabular}{|c|c|c|c|c|}
\hline Factor & $K^{\mathrm{a}}$ & $Y_{b}^{\mathrm{b}}(\%)$ & $P F_{b}{ }^{\mathrm{c}}$ & $F A_{b}{ }^{\mathrm{d}}(\mathrm{U} / \mathrm{mL})$ \\
\hline$C_{P E G^{\mathrm{e}}}(\mathrm{L})^{\mathrm{f}}$ & $3.24^{*}$ & $-6.13^{*}$ & $6.91^{*}$ & -0.28 \\
\hline$C_{P E G}{ }^{\mathrm{e}}(\mathrm{Q})^{\mathrm{g}}$ & $-4.08^{*}$ & 0.51 & $3.43^{*}$ & 1.04 \\
\hline$C_{\mathrm{Na} 2 \mathrm{SO} 4^{\mathrm{h}}}(\mathrm{L})^{\mathrm{f}}$ & $3.90^{*}$ & 0.79 & $3.85^{*}$ & 0.18 \\
\hline$C_{\mathrm{Na2SO}^{\mathrm{h}}}^{\mathrm{h}}(\mathrm{Q})^{\mathrm{g}}$ & 1.06 & 2.69 & -2.11 & -3.72 \\
\hline$C_{P E G}{ }^{\mathrm{e}}(\mathrm{L})^{\mathrm{f}} \times C_{N a 2 S O 4^{\mathrm{h}}}(\mathrm{L})^{\mathrm{f}}$ & $-4.06^{*}$ & 1.73 & $4.90^{*}$ & -2.62 \\
\hline
\end{tabular}

a $K=$ Partition coefficient.

b $Y_{b}=$ Activity yield in the bottom phase.

c $P F_{b}=$ Purification factor in the bottom phase.

d $F A_{b}=$ Fibrinolytic activity in the bottom phase.

e $C_{P E G}=$ PEG 6000 concentration.

${ }^{f} \mathrm{~L}=$ Linear effects.

g $\mathrm{Q}=$ Quadratic effects.

h $C_{\mathrm{Na2SO} 4}=$ Sodium sulfate concentration.

* Statistically significant effects $(P$-value $<0.05)$.

\subsection{Amidolytic activity and effect of inhibitors on protease activity}

As far as the amidolytic activity of the purified fibrinolytic protease is concerned, succinyl-L-ala-ala-pro-L-phenylalanine- $p$ - nitroanilide (SAPNA), a typical substrate of chymotrypsin, was shown to be the most effective among all other substrates tested 
Table 4

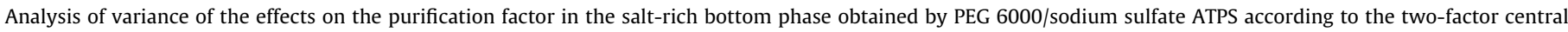
composite rotary design.

\begin{tabular}{|c|c|c|c|c|c|}
\hline Factor & $\mathrm{SS}^{\mathrm{a}}$ & $\mathrm{DF}^{\mathrm{b}}$ & MS $^{c}$ & $F$-value & $P$-value \\
\hline$C_{P E G}{ }^{\mathrm{d}}(\mathrm{L})^{\mathrm{e}^{*}}$ & 30.3801 & 1 & 30.3801 & 47.7621 & 0.0062 \\
\hline$C_{P E G}{ }^{\mathrm{d}}(\mathrm{Q})^{\mathrm{f}, *}$ & 7.5192 & 1 & 7.5192 & 11.8214 & 0.0412 \\
\hline$C_{\mathrm{Na} 2 \mathrm{SO} 4^{\mathrm{g}}}(\mathrm{L})^{\mathrm{e}, *}$ & 9.4769 & 1 & 9.4769 & 14.8991 & 0.0307 \\
\hline$C_{\mathrm{Na} 2 \mathrm{SO}^{\mathrm{g}}}(\mathrm{Q})^{\mathrm{f}}$ & 2.8499 & 1 & 2.8499 & 4.4805 & 0.1245 \\
\hline$C_{P E G}^{\mathrm{d}}(\mathrm{L})^{\mathrm{e}} \times C_{\mathrm{Na} 2 \mathrm{SO}^{\mathrm{g}}}(\mathrm{L})^{\mathrm{e}, *}$ & 15.3275 & 1 & 15.3275 & 24.0972 & 0.0161 \\
\hline Lack of fit & 9.2865 & 3 & 3.0955 & 4.8666 & 0.1131 \\
\hline Pure error & 1.9082 & 3 & 0.6360 & - & - \\
\hline Total SS & 79.1095 & 11 & - & - & - \\
\hline
\end{tabular}

a $\mathrm{SS}=$ Sum of squares

b $\mathrm{DF}=$ Degree of freedom.

c $\mathrm{MS}=$ Mean square.

d $C_{P E G}=$ PEG 6000 concentration

e $\mathrm{L}=$ Linear effects.

f $\mathrm{Q}=$ Quadratic effects.

g $C_{\mathrm{Na2SO4}}=$ Sodium sulfate concentration.

* Statistically significant effects $(P$-value $<0.05)$.

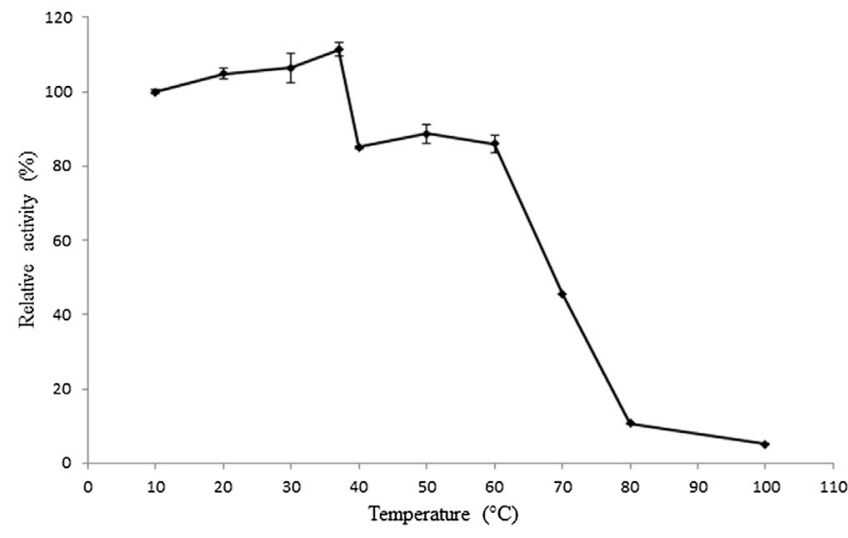

A

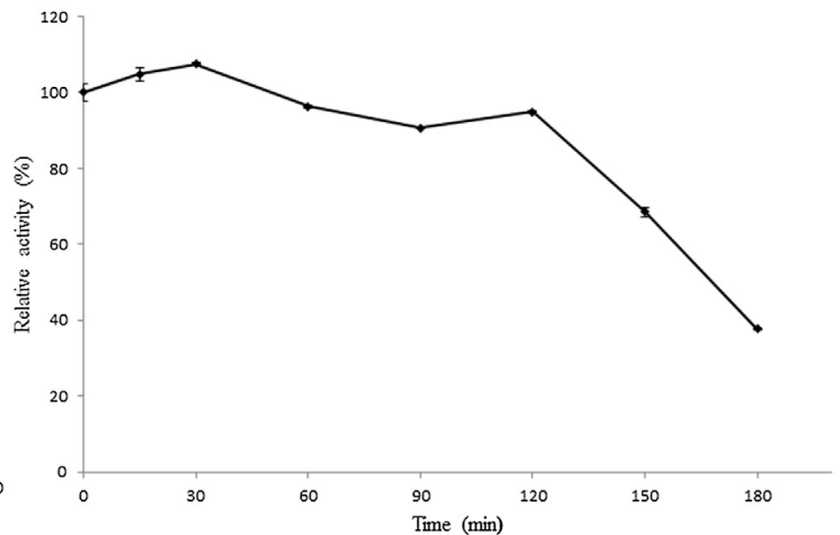

B

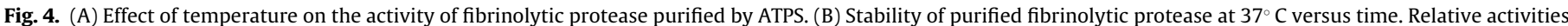
do refer to the activity at $10^{\circ} \mathrm{C}$ in (A) and the starting activity in (B).

Table 5

Amidolytic activity of fibrinolytic protease partitioned to the salt-rich bottom phase of PEG 6000/sodium sulfate ATPS.

\begin{tabular}{lll}
\hline Substrate & Enzyme & Amidolytic activity \\
\hline S7388 & Chymotrypsin & positive effect \\
G8148 & Plasmin and urokinase & negative effect \\
B4875 & Trypsin & negative effect \\
\hline
\end{tabular}

Table 6

Effect of inhibitors on protease activity of fibrinolytic protease partitioned to the salt-rich bottom phase of PEG 6000/sodium sulfate ATPS.

\begin{tabular}{ll}
\hline Inhibitor & Residual activity (\%) \\
\hline Control & 100 \\
EDTA & 100 \\
$\beta$-Mercaptoethanol & 97.7 \\
PMSF & $0.00^{*}$ \\
Pepstatin A & 91.3 \\
Iodoacetic acid & 100 \\
\hline
\end{tabular}

a $\mathrm{PMSF}=$ phenylmethylsulfonyl fluoride.

* Statistically significant effects $(P$-value $<0.05)$.

(Table 5), which suggests that the enzyme may be a chymotrypsinlike protease, similar to other fibrinolytic enzymes [42].

On the other hand, the effect of various inhibitors on protease activity is summarized in Table 6. Our fibrinolytic protease was completely inhibited by phenylmethylsulfonyl fluoride (PMSF), a
Table 7

Effect of metal ions on protease activity of fibrinolytic protease partitioned to the salt-rich bottom phase of PEG 6000/sodium sulfate ATPS.

\begin{tabular}{llll}
\hline \multicolumn{4}{l}{ Residual activity (\%) } \\
\hline Metal ion & $2.5 \mathrm{mM}$ & $5.0 \mathrm{mM}$ & $10 \mathrm{mM}$ \\
Control & 100.00 & 100.00 & 100.00 \\
$\mathrm{~K}^{+}$ & 93.86 & 93.86 & 100.0 \\
$\mathrm{Ca}^{++}$ & $119.09^{*}$ & $107.50^{*}$ & 102.27 \\
$\mathrm{Mn}^{++}$ & $109.31^{*}$ & $107.50^{*}$ & 100.90 \\
$\mathrm{Zn}^{++}$ & $89.77^{*}$ & $76.36^{*}$ & $30.00^{*}$ \\
$\mathrm{Mg}^{++}$ & 102.50 & 92.73 & $110.91^{*}$ \\
$\mathrm{Co}^{++}$ & $65.68^{*}$ & $72.50^{*}$ & $61.59^{*}$ \\
$\mathrm{Cu}^{++}$ & $66.13^{*}$ & $57.95^{*}$ & $54.09^{*}$ \\
$\mathrm{Fe}^{++}$ & $75.68^{*}$ & $66.59^{*}$ & $52.95^{*}$ \\
$\mathrm{Na}^{+}$ & 91.59 & 91.59 & 98.40 \\
\hline
\end{tabular}

* Statistically significant effects $(P$-value $<0.05)$

well-known inhibitor of serine protease. This result corroborates those of Peng et al. [43], who purified a fibrinolytic enzyme that behaved similarly to serine protease.

\subsection{Effect of metal ions on protease activity}

The effect of different metal ions was also investigated on the residual activity of protease from $M$. subtilissimus extracted by ATPS using PEG $6000(30 \% \mathrm{w} / \mathrm{w})$ and $\mathrm{Na}_{2} \mathrm{SO}_{4}(13.2 \% \mathrm{w} / \mathrm{w})$. As shown in Table 7 , this activity was enhanced by $\mathrm{Ca}^{++}$and $\mathrm{Mn}^{++}$both at concentrations of 2.5 and $5.0 \mathrm{mM}$, and by $\mathrm{Mg}^{++}$at concentration 
of $10.0 \mathrm{mM}$, confirming the results reported by Kim et al. [44] for a similar enzyme, whereas it was strongly inhibited by $\mathrm{Co}^{++}, \mathrm{Cu}^{++}$ and $\mathrm{Fe}^{++}$at all the concentrations tested. This result is consistent with those of other researchers, who observed inhibiting effects of $\mathrm{Cu}^{++}$[45], $\mathrm{Fe}^{++}$[46], $\mathrm{Cu}^{++}$and $\mathrm{Co}^{++}$[47] on the activities of other purified fibrinolytic enzymes. On the contrary, the other metal ions $\left(\mathrm{K}^{+}, \mathrm{Na}^{+}\right.$and $\left.\mathrm{Zn}^{++}\right)$did not exert any significant effect on residual enzyme activity.

\subsection{Effect of temperature on protease activity and stability}

Fig. 4 shows that the purified enzyme displayed its maximum activity at $37^{\circ} \mathrm{C}$, confirming the results reported by Lu et al. [45] for a novel fibrinolytic enzyme from Paenibacillus polymyxa EJS3 (HIPC-I) purified by chromatography methods. This comparison underscores the relevance of the results of this work based on the use of a cheap purification method like ATPS in comparison with those obtained employing more expensive and time-consuming multi-steps methods. The enzyme became less active when temperature was raised to $60^{\circ} \mathrm{C}$, and was completely denatured at temperatures $>80^{\circ} \mathrm{C}$ (Fig. $4 \mathrm{~A}$ ).

Thermal stability studies showed that the purified fibrinolytic protease was quite stable at $37^{\circ} \mathrm{C}$ (optimal temperature for fibrinolytic activity), and its residual activity was 94 and $68 \%$ of the initial one after 120 and 150 min respectively (Fig. 4B).

\section{Conclusions}

Aqueous two-phase systems (ATPS) using PEG 6000 and $\mathrm{Na}_{2} \mathrm{SO}_{4}$ were used to select the optimal conditions to recovery a fibrinolytic acidic protease from Mucor subtlilissimus UCP 1262. To this purpose, extraction tests were carried out according to a two-factor central composite rotary design, where the concentrations of PEG $\left(C_{P E G}\right)$ and $\mathrm{Na}_{2} \mathrm{SO}_{4}\left(C_{\mathrm{Na2SO}}\right)$ were used as the independent variables, and the partition coefficient, the fibronolytic activity, activity yield and purification factor in the bottom phase as the responses. Optimal conditions were shown to be $C_{P E G}$ of $30.0 \%(\mathrm{w} / \mathrm{w})$ and $C_{\mathrm{Na2SO}}$ of $13.2 \%(w / w)$. Results clearly showed a high purification degree of the enzyme in the salt-rich bottom phase. The enzyme, which was characterized as a chymotrypsin-like protease, exhibited an optimal temperature for fibrinolytic activity of $37^{\circ} \mathrm{C}$, at which it was quite stable, and had its activity increased in the presence of some metal ions $\left(\mathrm{Ca}^{++}, \mathrm{Mn}^{++}\right.$and $\left.\mathrm{Mg}^{++}\right)$or decreased in the presence of others $\left(\mathrm{Co}^{++}, \mathrm{Cu}^{++}\right.$and $\left.\mathrm{Fe}^{++}\right)$. This work demonstrates the potential of ATPS as primary recovery step for the extraction/purification of fibrinolytic proteases.

\section{Acknowledgments}

The authors acknowledge the financial support of the Brazilian Coordenação de Aperfeiçoamento de Pessoal de Nível Superior (CAPES), Fundação de Amparo à Ciência e Tecnologia do Estado de Pernambuco (FACEPE), and Conselho Nacional de Desenvolvimento Científico e Tecnológico (CNPq). The authors also thank the project approved in the RENNORFUN network (MCT/CNPq/MMA/MEC/CAPES/FNDCT, Ação Transversal/FAPs, No.47/2010, Sistema Nacional de Pesquisa em Biodiversidade - SISBIOTA/Brazil).

\section{References}

[1] K. Inokuma, M. Takano, K. Hoshino, Direct ethanol production from $\mathrm{N}$-acetylglucosamine and chitin substrates by Mucor species, Biochem. Eng. J. 72 (2013) 24-32.

[2] S. Yegin, M. Fernandez-Lahore, A.J.G. Salgado, U. Guvenc, Y. Goksungur, C. Tari, Aspartic proteinases from Mucor spp. in cheese manufacturing, Appl. Microbiol. Biotechnol. 89 (2011) 949-960.
[3] G. Ravikumar, D. Gomathi, M. Kalaiselvi, C. Uma, A protease from the medicinal mushroom Pleurotus sajor-caju; production, purification and partial characterization, Asian Pac. J. Trop. Med. 2 (2012) S411-S417.

[4] S.K. Rai, A.K. Mukherjee, Ecological significance and some biotechnological application of an organic solvent stable alkaline serine protease from Bacillus subtilis strain DM-04, Bioresour. Technol. 100 (2009) 2642-2645.

[5] F.E.F. Soares, F.R. Braga, J.V. Araújo, H.L.A. Geniêr, A.S. Gouveia, J.H. Queiroz, Nematicidal activity of three novel extracellular proteases of the nematophagous fungus Monacrosporium sinense, Parasitol. Res. 112 (2013) 1557-1565.

[6] G.M. Medeiros e Silva, D.A.V. Marques, T.S. Porto, J.L. Lima-Filho, J.A.C. Teixeira, A. Pessoa-Júnior, A.L.F. Porto, Extraction of fibrinolytic proteases from Streptomyces sp. DPUA1576 using PEG-phosphate aqueous two-phase systems, Fluid Phase Equilib. 339 (2013) 52-57.

[7] P. Palanivel, L. Ashokkumar, R. Balagurunathan, Production, purification and fibrinolytic characterization of alkaline protease from extremophilic soil fungi, Int. J. Pharm. Biol. Sci. 4 (2) (2013) B101-B110.

[8] A.C.O. Cintra, L.G.B. Toni, M.A. Sartim, Batroxase, a new metalloproteinase from B. atrox snake venom with strong fibrinolytic activity, Toxicon 60 (2012) 70-82.

[9] G.K. Patel, A.A. Kawale, A.K. Sharma, Purification and physicochemical characterization of a serine protease with fibrinolytic activity from latex of a medicinal herb Euphorbia hirta, Plant Physiol. Biochem. 52 (2012) 104-111.

[10] N. Shirasaka, M. Naitou, K. Okamura, M. Kusuda, Y. Fukuta, T. Terashita, Purification and characterization of a fibrinolytic protease from Aspergillus oryzae KSK-3, Mycoscience 53 (2012) 354-364

[11] S. Germano, A. Pandey, C.A. Osaku, S.N. Rocha, C.R. Soccol, Characterization and stability of proteases from Penicillium sp produced by solid-state fermentation, Enzyme Microb. Technol. 32 (2003) 246-251.

[12] E. Bach, V. Sant'Anna, D.J. Daroit, A.P.F. Corrêa, J. Segalin, A. Brandelli, Production, one-step purification and characterization of a keratinolytic protease from Serratia marcescens P3, Process Biochem. 47 (2012) 2455-2462.

[13] M.L.C. Neves, T.S. Porto, C.M. Souza-Motta, M.R. Spier, C.R. Soccol, K.A. Moreira, A.L.F. Porto, Partition and recovery of phytase from Absidia blakesleeana URM5604 using PEG-citrate aqueous two-phase systems, Fluid Phase Equilib. 318 (2012) 34-39.

[14] S. Raja, V.R. Murty, V. Thivaharan, V. Rajasekar, V. Ramesh, Aqueous two phase systems for the recovery of biomolecules-a review, Sci. Technol. 1 (2011) 7-16

[15] G. Tubio, B.B. Nerli, G.A. Picó, A. Venâncio, J. Teixeira, Liquid-liquid equilibrium of the Ucon 50-HB5100/sodium citrate aqueous two-phase systems, Sep. Purif. Technol. 65 (2009) 3-8.

[16] L.S. Kirsch, A.C.S. Pinto, M.F.S. Teixeira, T.S. Porto, A.L.F. Porto, Partition of proteases from Lentinus citrinus DPUA 1535 by the Peg/phosphate aqueous two-phase system, Quim. Nova 35 (2012) 1912-1915.

[17] P.P. Madeira, J.A. Teixeira, E.A. Macedo, L.M. Mikheeva, B.Y. Zaslavsky, Correlations between distribution coefficients of various biomolecules in different polymer/polymer aqueous two-phase systems, Fluid Phase Equilib. 267 (2008) 150-157.

[18] D.-S. Wang, C.-C. Torng, I.-P. Lin, B.-W. Cheng, H.-R. Liu, C.-Y. Chou, Optimization of nattokinase production conduction using response surface methodology, J. Food Process Eng. 29 (2006) 22-35.

[19] V. Deepak, S. Ilangovan, M.V. Sampathkumar, M.J. Victoria, S.P.B.S. Pasha, S.B.R.K. Pandian, S. Gurunathan, Medium optimization and immobilization of purified fibrinolytic URAK from Bacillus cereus NK1 on PHB nanoparticles, Enzyme Microb. Technol. 47 (2010) 297-304.

[20] J.-K. Wang, H.-H. Chiu, C.-S. Hsieh, Optimization of the medium components by statistical experimental methods to enhance nattokinaseactivity, Fooyin J. Health Sci. 1 (2009) 21-27

[21] O.K. Ashipala, Q. He, Optimization of fibrinolytic enzyme production by Bacillus subtilis DC-2 in aqueous two-phase system (poly-ethylene glycol 4000 and sodium sulfate), Bioresour. Technol. 99 (2008) 4112-4119.

[22] V. Deepak, K. Kalishwaralal, S. Ramkumarpandian, S.V. Babu, S.R. Senthilkumar, G. Sangiliyandi, Optimization of media composition for nattokinase production by Baciillus subtilis using response surface methodology, Bioresour. Technol. 99 (2008) 8170-8174.

[23] T.P. Nascimento, A.E. Sales, C.S. Porto, R.M.P. Brandão, G.M.C. Takaki, J.A.C. Teixeira, T.S. Porto, A.L.F. Porto, Production and characterization of new fibrinolytic protease from Mucor subtilissimus UCP 1262 in solid-state fermentation, Adv. Enzyme Res. 8 (2015) 81-91.

[24] C.L. Ginther, Sporulation and the production of serine protease and cephamycin C by Streptomyces lactamdurans, Antimicrob. Agents Chemother 15 (1979) 522-526

[25] S.L. Wang, Y.Y. Wu, T.W. Liang, Purification and biochemical characterization of a nattokinase by conversion of shrimp shell with Bacillus subtilis TKU007, New Biotechnol. 28 (2011) 196-202.

[26] M.M. Bradford, A rapid and sensitive method for the quantitation of microgram quantities of protein utilizing the principle of protein-dye binding, Anal. Biochem. 72 (1976) 248-254.

[27] B. Barros Neto, I.C. Scarminio, R.E. Bruns, Como Fazer Experimentos: Pesquisa E Desenvolvimento Na Ciência E Na Indústria, second ed., Editora da UNICAMP, Campinas, SP, Brazil, 2002.

[28] U.K. Laemmli, Cleavage of structural proteins during the assembly of the head of bacteriophage T4, Nature 227 (1970) 680-685.

[29] S.H. Kim, N.S. Choi, W.Y. Lee, Fibrin zymography: a direct analysis of fibrinolytic enzymes on gels, Anal. Biochem. 263 (1998) 115-116. 
[30] W. Kim, K. Choi, Y. Kim, H. Park, J. Choi, Y. Lee, H. Oh, I. Kwon, S. Lee, Purification and characterization of a fibrinolytic enzyme produced from Bacillus sp. strain CK 11-4 screened from Chungkook-Jang, Appl. Environ. Microbiol. 62 (1996) 2482-2488.

[31] A.E. Sales, F.A.S.D. Souza, J.A. Teixeira, T.S. Porto, A.L.F. Porto, Integrated process production and extraction of the fibrinolytic protease from Bacillus sp. UFPEDA 485, Appl. Biochem. Biotechnol. 170 (2013) 1676-1688.

[32] G. Reh, D. Spelzini, G. Tubio, G. Picó, B. Farruggia, Partition features and renaturation enhancement of chymosin in aqueous two-phase systems, J. Chromatogr. B 860 (2007) 98-105.

[33] J.T. Faria, F.C. Sampaio, A. Converti, F.M.L. Passos, V.P.R. Minim, L.A. Minim, Use of response surface methodology to evaluate the extraction of Debaryomyces hansenii xylose reductase by aqueous two-phase system, J. Chromatogr. B 877 (2009) 3031-3037.

[34] M.T.H. Cavalcanti, T.S. Porto, B.B. Neto, J.L. Lima-Filho, A.L.F. Porto, A. Pessoa-Junior, Aqueous two-phase systems extraction of $\alpha$-toxin from Clostridium perfringens type A, J. Chromatogr. B 833 (2006) 135-140.

[35] L.H. Haraguchi, R.S. Mohamed, W. Loh, P.A. Pessôa-Filho, Phase equilibrium and insulin partitioning in aqueous two-phase systems containing block copolymers and potassium phosphate, Fluid Phase Equilib. 215 (2014) 1-15.

[36] P. Patcharaporn, A.K. Aran, M. Ohsugi, Y. Dissara, Production and properties of a fibrinolytic enzyme by Schizophyllum commune BL23, Songklanakarin J. Sci. Technol. 30 (2008) 447-453.

[37] J.I. Rovati, O.D. Delgado, L.I.C. Figueroa, J.I. Fariña, A novel source of fibrinolytic activity: Bionectria sp. an unconventional enzyme-producing fungus isolated from Las Yungas rainforest (Tucumán, Argentina), World J. Microbiol. Biotechnol. 26 (2010) 55-62.

[38] S. Sugimoto, T. Fugii, T. Morimyia, O. Johdo, T. Nakamura, The fibrinolytic activity of a novel protease derived from a Tempeh producing fungus, Fusarium sp. BLB, Biosci. Biotechnol. Biochem. 71 (2007) 2184-2189.

[39] X.-L. Liu, L.-X. Du, F.-P. Lu, X.-Q. Zheng, J. Xiao, Purification and characterization of a novel fibrinolytic enzyme from Rhizopus chinensis 12 Appl. Microbiol. Biotechnol. 67 (2005) 209-214.
[40] W.-S. Cha, S.-S. Park, S.-J. Kim, D. Choi, Biochemical and enzymatic properties of a fibrinolytic enzyme from Pleurotus eryngii cultivated under solid-state conditions using corncob, Bioresour. Technol. 101 (2010) 6475-6481.

[41] C.-L. Lu, S. Chen, S.-N. Chen, Purification and characterization of a novel fibrinolytic protease from Schizophyllum commune, J. Food Drug Anal. 18 (2010) 69-76.

[42] C.-T. Chang, P.-M. Wang, Y.-F. Hung, Y.C. Chung, Purification and biochemical properties of a fibrinolytic enzyme from Bacillus subtilis-fermented red bean, Food Chem. 133 (2012) 1611-1617.

[43] Y. Peng, Q. Huang, R.-H. Zhang, Y.-Z. Zhang, Purification and characterization of a fibrinolytic enzyme produced by Bacillus amyloliquefaciens DC-4 screened from douchi, a traditional Chinese soybean food, Comp. Biochem. Physiol. B-Biochem. Mol. Biol. 134 (2003) 45-52.

[44] J.-S. Kim, J.-E. Kim, B.-S. Choi, S.-E. Park, K. Sapkota, S. Kim, H.-H. Lee, C.-S. Kim, Y. Park, M.-K. Kim, Y.-S. Kim, S.-J. Kim, Purification and characterization of fibrinolytic metalloprotease from Perenniporia fraxinea mycelia, Mycol. Res. 112 (2008) 990-998.

[45] F. Lu, Z. Lu, X. Bie, Z. Yao, Y. Wang, Y. Lu, Y. Guo, Purification and characterization of a novel anticoagulant and fibrinolytic enzyme produced by endophytic bacterium Paenibacillus polymyxa EJS-3, Thromb. Res. 126 (2010) e349-e355.

[46] C.T. Wang, B.P. Ji, B. Li, R. Nout, P.L. Li, H. Ji, L.F. Chen, Purification and characterization of a fibrinolytic enzyme of Bacillus subtilis DC33, isolated from Chinese traditional Douchi, J. Ind. Microbiol. Biotechnol. 33 (2006) $750-758$.

[47] S.-M. Moon, J.-S. Kim, H.-J. Kim, M.S. Choi, B.R. Park, S.-G. Kim, H. Ahn, H.S Chun, Y.K. Shin, J.-J. Kim, D.K. Kim, S.-Y. Lee, Y.-W. Seo, Y.H. Kim, C.S. Kim, Purification and characterization of a novel fibrinolytic $\alpha$ chymotrypsin like serine metalloprotease from the edible mushroom, Lyophyllum shimeji, J. Biosci. Bioeng. 117 (2014) 544-550. 